NBER WORKING PAPERS SERIES

\title{
STABILIZATION AND LIBERALIZATION POLICIES \\ IN CENTRAL AND EASTERN EUROPE: \\ LESSONS FROM LATIN AMERICA
}

Sebastian Edwards

Working Paper No. 3816

NATIONAL BUREAU OF ECONOMIC RESEARCH

1050 Massachusetts Avenue

Cambridge, MA 02138

August 1991

This paper is part of NBER's research program in International studies. Any opinions expressed are those of the author and not those of the National Bureau of Economic Research. 
NBER Working Paper \#3816

August 1991

STABILIZATION AND LIBERALIZATION POLICIES IN CENTRAL AND EASTERN EUROPE: LESSONS FROM LATIN AMERICA

\begin{abstract}
This paper discusses some economic problems faced by the Eastern European nations in light of recent Latin American experiences. The paper first argues that in spite of some important cultural, political and institutional differences, there are indeed some similarities between Eastern European and Latin American economic problems. The discussion concentrates on four specific areas: (1) monetary overhang and repressed inflation; (2) fiscal imbalances and inflationary pressures; (3) deindexation and inflationary inertia; and (4) the use of the exchange rate as a nominal anchor. It is argued that in chile the reliance on a price jump to solve the money overhang problem of 1973 created high inflationary expectations, increasing the degree of inertia of inflation. It is also pointed out that the Latin American experience tells a serious cautionary tale regarding the use of nominal exchange rate anchors. More often than not these types of policies have resulted in overvaluation, losses in international competitiveness and eventual external sector crises. A comparison of the Chilean and Mexican stabilization programs suggest that the use of exchange rate anchors will be more effective (and more credible) if the fixing of the exchange rate is accompanied by other policies geared at breaking inertia. Among these policies the most important one is the abandonment of wage rate indexation practices.
\end{abstract}

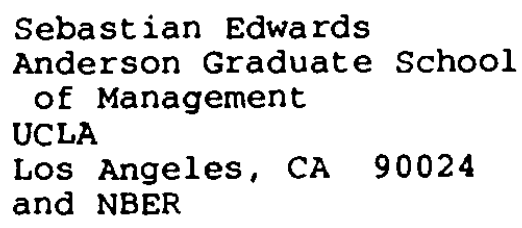




\section{Introduction}

In many ways 1989 and 1990 have been magical years, as we have seen the end of the cold War and the beginning of an exciting perlod of political and economic reconstruction in Central and Eastern Europe, and an era that promises great opportunities for the world economy. ${ }^{1}$ As they abandon the doctrines and policies of Communism, the nations of Eastern Europe face the Immense challenge of Implementing an efficlent and effective transition to a market-oriented economic regime. What makes the transitional issue particularly difficult is that the peoples of the Eastern European nations have placed their hopes of a dramatically rapid improvement in their standard of living on the implementation of the market-oriented reforms. To the extent that these reforms fall, or if the transition is percelved as being unduly costly, disillusionment and frustration will settle in, generating serlous social and political unrest with unpredictable consequences.

In designing policy packages for the transition to free-markets, the Eastern European countries face three main problems: First, how to stabllize their economies, achleving internal and external macroeconomic balance; second, how to implement the structural and market-oriented reforms in an orderly and effective way; and third, how to proceed with the privatization process. In dealing with these important questions the political leaders and their technical advisers have had to confront two particularly pressing issues related to the speed of sequencing of reforms. With respect to stabilization policles, the most important controversies refer to: (1) how to solve the situation of monetary overhang - either through a monetary

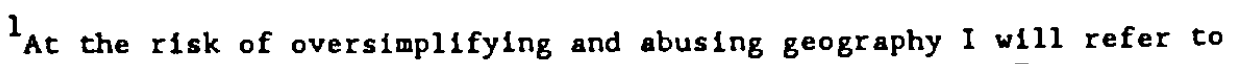
the former communist nations plus the Soviet Union as Eastern European countries. 
reform or an adjustment of the price level; (2) whether the anti-1nflationary program should be based on an exchange rate or monetary anchor; and the extent to which the labor market should be reformed and deindexed.

In terms of structural, market-orlented reforms, the key questions are how fast and in what sequence the opening of the external sector and the creation of a domestic financial market should take place. In this area the 1ssue of bankruptcy laws has also been hotly debated. Finally, with regard to privatization the key discussions have centered on whether firms should be sold or transferred to the public, or how fast this process should take place, and on whether forelgn investors should be allowed to participate in the participation. ${ }^{2}$

Reform packages have been rapidly implemented in Poland and Yugoslavia since early 1990, and are now beginning to be 1mplemented in Czechoslovakla. The liberalization and stabilization programs in Poland and Yugoslavia exhibit a number of striking similarities. ${ }^{3}$ Both countries, for Instance, freed prices, devalued abruptly, and decided to rely on a major price level adjustment to solve the monetary overhang problem. The two countries immediately declared (partial) convertibllity of thelr currencles, and subsequently fixed the nominal exchange rate in an attempt to provide an anchor for the price system. While in Poland the fixed rate policy continues to the time of this writing, In Yugoslavia a (substantial) devaluation was implemented in the first week of 1991. Both countries increased interest rates as a way to control aggregate demand, and announced (but not quite lmplemented) tough bankruptcy laws. Additionally, they both

2 On controversies regarding the Eastern European reforms, see, for example, Hinds (1990), Lipton and Sachs (1990) and Nordhaus (1990).

${ }^{3}$ For an 1lluminating comparison see Covicell1 and Rocha (1990). 
partially deindexed wages in an effort to reduce inflation inertia. Also, in both nations there have been announcements of sweeping privatization that have not yet materialized in any significant way.

In spite of some clear successes, such as a reduction in inflation in the second and third quarters of 1990, the (1nitial) elimination of the black market premium and the generation of a trade surplus, both Poland and Yugoslavia are currently facing some serlous problem. Although inflation is lower than in the first months of the programs it 1s, especially in Poland, st1ll significantly higher than expected. In Yugoslavia the republics have challenged the central authority's austerity adjustment programs. Unemployment has climbed rapidly and industrial production has plumeted. In light of these results, a number of observers are asking themselves whether other (former) socialist nations, and the USSR in particular, should follow similar programs or $1 f$, on the contrary, they should Implement alternative paths.

Although strictly speaking the Eastern European experiments have no direct precedents, there are some historical eplsodes that can shed some light and provide important lessons on individual aspects of the free market transformations. For 1nstance the post-World War II European experience with monetary overhang and monetary reforms offers potentially important lessons on how to tackle a situation of major monetary disequllibrium cum rationing. Also, the large number of stabilization attempts in Latin America during the last four decades provide a wealth of lessons - - both positive and negative - on different aspects of anti-inflationary programs.

From a historical and comparative perspective the largely successful stabilization and liberalization experiences in Chile and Mexico in the last 15 years offer particularly Important lessons for Eastern European leaders and their advisors. In both of these countries inflation has been 
significantly reduced, the external sector has been practically open to free trade, dynamic domestic financial markets have been created, vigorous privatization programs have been enacted, and an increasingly strong record of growth has been established. In fact as can be seen from Figure 1, Chile, Mexico (and Bolivia) have recently been able to (partially) conquer extreme inflations. 4 An important difference between the Chilean and Mexican experiences is that while in Chile stabilization was very gradual, the reduction of inflation to manageable levels was achleved quite rapidly in Mexico: while in Chile it took 25 quarters to reduce inflation from its peak to below 58 per quarter, In Mexico it only took 6 quarters to accomplish this task. ${ }^{5}$

The purpose of this paper is to discuss some Latin American lessons on stabilization that can be useful to better understand the policy options avallable to the former socialist nations. Although the analysis focuses on stabilization, I also make some reference to privatization and other market. orlented policles. Throughout the discussion I mostly concentrate on the case of Chile. The reasons for focusing on Chile are several: first in 1973 Chile faced initial conditions that in some respects, are as close to those of Eastern Europe as they can possibly be: second, during the last 15 years Chile experimented with a series of alternative policies, providing a fascinating laboratory of sorts; third, in contrast with many other Latin

4 The main difference between these three cases is that while in Mexico and Chile stabilization has been accompanied by recovery and growth, Bolivia has remained basically stagnant. Also, due to Bolivia's lower level of development, lessons derived from its experience are less valuable for Eastern Europe.

${ }^{5}$ Notice, however, that this comparison is in a way unfair since the peak quarterly rate of inflation was much higher in Chile than in Mexico. In Chile this peak was achleved in the second quarter of 1974, where inflation reached 98.38, in Mexico the peak was in the second quarter of 1983 with a rate of inflation of 23.48 . 
American eplsodes. Chile's pollcles in the 1970s and 1980 s dealt with both stabllization and liberalization (Including a major privatization program); and finally, Chile represents a successful transition from a highly Inflationary and tightly controlled economy into a market-oriented and stable one. The degree of success of the Chllean experience is clearly underscored by the fact that the newly elected democratic government of President Patriclo Aylwin has decided to maintain in place the vast majority of the economic reforms implemented during the Pinochet regime. 6

Polltically, of course, the cruclal difference between Chile and Eastern Europe is that while ChIle's reforms were undertaken by dictatorial rule, the Eastern European programs are belng carrled out by (mostly) democratic governments. This difference, in fact, should not be underestimated in comparing the specific experiences in these two regions. Some of the pollcles implemented in Chile may prove to be too unpopular to sustain in a democratic regime.

Another key difference between Ch1le and Eastern Europe is that in 1973 Chile had already in place a large number of fundamental market-oriented institutions. In fact, in spite of the decades of government intervention and controls, Chlleans had basically lived under a controlled market system. Th1s, of course, means that the challenge faced by the Eastern European nations is tremendous: creating market institutions from scratch is a task of Herculean proportions that shouldn't be underestimated.

The rest of the paper is organized as follows: in section II. I deal at an analytical level with four of the most 1mportant macroeconomic problems faced by the former soclallst economies embarked on stabllization

${ }^{6}$ On the way the new democratlc government has dealt with the Plnochet economlc legacy, see Edwards and Edwards (1991). 
programs: (1) alternative ways of dealing with the monetary overhang and rationing: (2) fiscal equilibrium and the reduction of inflation;

(3) the use of fixed nominal exchange rates as an anchor in the ant 1inflationary policy; and (4) the role of Indexation and labor markets in the adjustment process. In Section III, I discuss some important Chilean (and Mexican) lessons regarding these four important areas of the stabilization prograns. In this section I argue that there are some very important stabilization lessons from Latin America for Easter Europe. In Section IV I provide the conclusions, including some remarks on structural reforms and privatization policies.

II. Stabilization and Liberalization in Eastern Europe: Problems. Controversies and Policies

The Initial conditions faced by reformers in Eastern Europe and the USSR can best be described as chaotic and unsustalnable. ${ }^{7}$ In almost every country - Including those already embarked in adjustment programs -. the combination of a growing monetary overhang with declining labor productivity has been translated into widespread rationing of consumer (and other) goods, and seriously wisaligned relative prices. This problem has been compounded by the fact that increasingly large fiscal deficits have been monetized putting additional pressure on the macroeconomy, generating an extremely critical balance of payments condition and making the repressed inflation particularly difficult to handle. Table 1 contalns some basic data on the performance of these economies in the second half of the 1980s. The fact that in a number of these countries the observed rates of inflation were rather low in 1989 is not a sign of financial stability but, on the

\footnotetext{
${ }^{7}$ A serious problem in evaluating the initial conditions in the Eastern European countries is that the data avallable are extremely poor.
} 
contrary, it is a reflection of the fact that the substantial accumulated monetary increases have not been allowed to reflect themselves on price increases. The result of this has been repressed inflation and an aggravation of generalized scarcity and rationing.

Stabilizing the economy is, without a doubt, a clear priority in any reform program for the (former) Communist countries. Most authors have, in fact, agreed on the urgency of stablilzation and on the fact that in any sequencing discussion, the Implementation of an anti-inflationary program should precede most other measures. There is much less agreement, however, on how to implement such a stabilization program and on how to deal, among other things, with money overhang, the fiscal disequilibrium, the exchange rate and the labor market. In this section I analyze some of the most important controversies surrounding stabilization in former (or disappearing) socialist countries. In the next section I expand the discussion by analyzing how the recent stabilization experiences in Chile and Mexico can help better understand some of the problems faced by the Eastern European pol lcymakers.

The implementation of stabilization programs is particularly difficult because, contrary to most modern experiences with macroeconomic crises, the USSR and Eastern European nations face both a stock and a flow macroeconomic disequilibrium. The stock disequilibrium which has generated a monetary overhang, has been the result of years of rapid money creation under generalized price controls, and declining productivity. This has provoked a situation where the actual (observed) income velocity is substantially below desired velocity of money, and where queues, and rationing are an everyday fact of 1ife. The flow disequilibrium, on the other hand, has been the result of large (and increasing) fiscal deficits, that have been monetized. 
There is virtual consensus among different analysts that a necessary early step in the reform process refers to eliminating the money overhang. At the same time there seems to be a clear understanding that the elimination of the stock excess supply of money will not eliminate the inflationary pressures in the system. This will require, in addition, significant fiscal adjustment that will greatly reduce, If not put a complete end to the fiscal deficit and inflationary monetary finance.

II.1 Eliminating the Monetary Disequilibrfum: Price Adjustment or Monetary Reform?

A situation of monetary overhang, or repressed inflation, results when increases in the stock of money take place in an environment of generalized price controls and rationing. In these circumstances not only does the economy face disequilibrium relative prices, but in addition the actual real stock of money (M/Py) exceeds the desired stock of money (M/Py)* -where the usual notation has been used:

$$
\frac{M}{\mathrm{Py}}>\left(\frac{M}{\mathrm{Py}}\right)^{\star}
$$

In these circumstances goods are rationed through queuing and/or a secondary black market. Clearly, then, there are "virtual" prices that clear the market for which there is no monetary disequilibrium. This, of course, does not eliminate the fact that these countries face a serious situation of repressed inflation.

An obvious, but nonetheless important implication of (1) is that there are four potential ways of solving a situation of monetary overhang: (1) a reduction of nominal money balances $M$ through some type of monetary reform; (2) a (supposedly) once-and-for-all increase in the domestic price level P; (3) an increase in domestic real output (y); and (4) a rise 
In the desired quanticy of money $(M / P y){ }^{*}{ }^{B}$ The last two alternatives . a major increase in real output and a signiflcant increase in the demand for money - are impractical, and Implausible; moreover, even if $y$ and $(M / P y) *$ do Increase, this will not happen with the speed required to solve the overhang problem in the short run. Th1s means that for all practical purposes we are left with (a discreet) price adjustment or a monetary reform as the two only practical ways to eliminate the money overhang. In both options it is 1mplicitly assumed that relative prices are allowed to adjust rapidly and to regain equilibrium.

Interestingly enough, while in the post World War II period most European nations opted for the monetary reform route, at the present time the Eastern European nations that have embarked on adjustment have chosen to rely on the price level adjustment approach. As pointed out in Section I. both Yugoslavia and Poland declded to handle the overhang by simultaneously freeing the vast majorlty of prices, declaring (partial) exchange rate convertiblity and englneering a major nominal devaluation. Some authors have criticlzed the use of this approach for solving the overhang in these countries and suggested that the best path for the Soviet Union 1 s to undertake a signiflcant and sweeping monetary reform. 9

${ }^{8}$ Naturally, a combination of these four mechanisms would also work. See Lipton and Sachs for a theoretical analysis of some of the most important aspects of monetary overhang.

${ }^{9}$ In modern Latin America the recent Collor de Mello stabilization plan in Braz1l constitutes the only experlence with monetary reform. However, partial reforms where a proportion of the public debt has been either blocked or transformed into lower value titles have taken place in a number of countries, Including Argentina and Chile. When the first version of this paper was written, the Soviet Union had not yet 1mplemented the 100 and 50 ruble bill confiscation process. As is pointed out below, this must have been the most clumsy monetary reform ever engineered. Dornbusch and Wolf (1990) argued for a monetary reform in the Soviet Union. 
Naturally, at the textbook level both of these alternatives are perfectly equivalent. While the monetary reform operates via the numerator of $(M / P y)$, the price level adfustment does it through the denominator. In more complicated economies, however, this equivalence does not hold. First, there are marked differences with respect to the administrative requirements for both policies. While a monetary reform requires a complicated and major logistic operation, the adjustment via prices is (almost) automatic. 10 Additionally, when implementing a monetary reform it has to be decided whether currency will be blocked, or confiscated. If blocked, for how long, and if confiscated, how much, and in what fashion? All of these are, of course difficult and time-consuming decisions. In fact, the most practically difficult problem associated with the implementation of a monetary reform is that the authorities have to have an approximate knowledge on the magnitude of the overhang. Miscalculations in this area can lead to serious losses in credibility. 11 The difficulty in estimating the approximate magnitude of the overhang is particularly serious in the case of Eastern European countries, where the historical data are not reliable, and where the structural and Institutional reforms will affect the demand for money in an unpredictable way. 12 This problem is neatly illustrated by the fact that there are several divergent estimates on the extent of the monetary overhang in the Soviet

${ }^{10}$ The degree of automaticity of the adjustment via the price level is particularly clear when the exchange rate is allowed to float. In both Poland and Yugoslavia, however, the exchange rate was fixed after the devaluation. I deal with this issue later.

11 Dornbusch and Wolff (1990) argue that it is possible to compute the (approximate) magnitude of the overhang by combining historical data on some benchmark (normal) year and estimates of black market activities.

12 Dornbusch and Wolf (1990) discuss a simple way of computing the approximate magnitude of the overhang. 
Union. While some authors argue that an elimination of the excess supply of money in that nation will require the doubling, or even tripling of the price level, others have pointed out that a 508 adjustment will probably be enough. 13 a particularly serlous problem occurs when the monetary reform is not accompanied by a very rapld price liberalization. In this case, as in the recent USSR attempt, the relaxation of repressed inflationary measures will be extremely short-lived, with the phenomenon of monetary overhang recurring quickly, and with even greater force.

An additional problem related to a monetary reform is that it may greatly afect the confidence in the domestic monetary system. To the extent that the public fears additional future confiscations or blockades, 1t will substitute away from domestic money and move towards real assets and foreign bank deposits. To the extent that this is indeed the case, the monetary reform per se would have generated additional macro-disequilibria, and fueled inflation. A final serlous problem confronted during monetary reforms refer to the issue of fairness and distributive effects. The most stralghtforward way of tackling this issue is by allowing each individual to exchange up to a certain amount of old money (currency and deposits) into new money. In this way the poorer segments will be relatively protected. This was not done in the recent Soviet reform, generating serlous (and possibly irreversible) loss in the confidence of the monetary system.

On the other hand, the price level adjustment alternative is not free of problems. In particular, it is unlikely that the price level will only experience the required corrective once-and-for-all fump. without having additional perverse effects on the rate of inflation. In fact, to the

${ }^{13}$ See, for example, the October/November 1990 is sue of The Internatienal Economy; see also Nordhaus (1990), and McKinnon (1990). 
extent that there are (Impliclt or explic1t) multiperlod contracts and Indexation, the major price level fump required to eliminate the overhang is likely to set in motion serlous inflationary pressures that w11l perpetuate themselves for several perlods. ${ }^{14}$ Moreover, to the extent that the Inltial price level fump generates expectations of further large price changes, desired velocity w1ll increase and economlc agents will try to anticlpate (expected) future inflation putting additional pressure into the system. Dornbusch and Wolf (1990) have recently argued that attempts to solve the monetary overhang through a price level adjustment can easily degenerate into unstable situations that can even lead to a hyperinflation. The fact that both In Poland and Yugoslavia, after the Initlal price level adjustment, over 50 of deposits are st1ll malntalned in forelgn currency can be Interpreted as a lack of confidence on the part of the public on the future of the stabllization program.

Recently some analysts, including the staff of the International Monetary Fund, have argued that it is possible to link the elimination of the money overhang to the privatization process. This would entall exchangIng the excess nominal money holdings for property titles to (some) of the newly privatized firms. 15 These proposals, however, miss the polnt that the elimination of the monetary overhang is a prerequisite for proceeding with almost every step in the reform process. Th1s means that the resolution of the stock monetary disequilibrlum has to take place very rapidly, and cannot walt for the legal and administrative requirements for a successful

${ }^{14}$ This w11l be the case even if there is partial indexation. Naturally, the more generalized indexation 1s, the more serlous this problem w1ll be.

${ }^{15}$ Hinds (1990) also discusses this posslbility. He 1s, however, quite critical about its applicability. 
privatization to be implemented.

In sum, then, at least in principle both basic methods for handling a situation of monetary overhang entall some risks. While a monetary reform, and especially one that errs on the estimated magnitude of the overhang, can generate serfous dislocations including a loss in the credibility of the domestic monetary system, a price level adjustment can generate additional Inflationary forces that, at least in theory, can explode into a hyperinflation. In fact, according to Dornbusch and Wolf (1990), four of the countries that opted for the price level adjustment in the post-World War II perlod, ended up facing major hyperinflations. What is clear, however, is that if the monetary reform route is chosen it is important not to use the pretext of the reform itself for delaying the freeing of prices and, thus, the correction of relative price distortions. Naturally, if prices are freed within the context of a monetary reform, their adjustment will be significantly less dramatic than if the program relies on price jumps only. In Section III, I discuss in detall the Chilean experience with the use of price level adjustments to solve its monetary overhang in late 1973. What makes the Chilean experience particularly important is that until the recent stabilization attempts in Eastern Europe. It constituted the only eplsode of monetary overhang elimination since the Second World War.

\section{II.2 Fiscal Discipline and the End of Inflation}

The elimination of monetary overhang will not put an end to inflation In Eastern Europe or the Soviet Union. Indeed, Inflationary pressures will only come to an end if the monetization of the fiscal deficit is eradicated. This means that efther fiscal deficits are reduced to levels compatible with foreign financing or that they are plainly reduced to zero. Naturally, a comprehensive approach to fiscal balance will require tackling the problem 
from both the revenue and expenditure side. This was indeed the plan in Poland and Yugoslavia, where the stabilization programs contemplated massive expenditure cuts - - mostly through the elimination of subsidies to stateowned firms $\cdots$ and an increase in revenues via the collection of dividends from public enterprises and higher compliancy and efficiency in tax collection. In both cases the inftial fiscal adjustment was substantial, allowing a closing of the gap between revenues and outlays. 16 In Yugoslavia, however, maintaining fiscal discipline has been extremely difficult in light of reglonal and political unrest.

Many stabilization programs, Including those undertaken to date in Eastern Europe, rely on an increase in the efficiency in tax collection as an 1mportant source for closing the fiscal gap. The main 1dea is that once the Initial measures (such as the freezing of the exchange rate) reduce inflation there w1ll be a reversed ollvera-Tanzi effect. ${ }^{17}$ Although there is some merit in this belief, there is a serlous risk of overestimating the actual importance of this phenomenon. This will be especially so in cases where the monetary overhang is handled through a price level adjustment, and where due to the existence of Indexation and medium term contracts, inflation will remain high for some time.

An efficient antidote to this problem, and one that has been tried in some Latin American nations such as Chile, is to enact an indexed tax system, where the corporate and other taxes are also subject to inflationary correction. An additional positive aspect of indexing the tax system is

${ }^{16}$ See, for Instance, Rocha (1990) and Covicell1 and Rocha (1990).

17 The olivera-Tanzi effect refers to the reduction in the real value, because of collection lags, of fiscal revenues during periods of increasing inflation. 
that it will tend to add credibility to the stabilization program.

The reduction, or elimination, of subsidies to public firms is another important traditional channel through which the fiscal gap can be closed. 18 This measure, which has recently been undertaken in both Poland and Yugoslavia, often results in firms incurring severe losses, and in an increase in their debt, some of which will eventually become bad debt. A potential problem is how to handle these losses and low quality debt once the decision to privatize is made. One possibility is to sell the firms, including the bad debt, at a relatively low price. This reflects the fact that the companies financial conditions are not fully healthy. This was, by and large, the procedure used during the first round of Chilean stabilizations in 1973-80 (see Edwards and Edwards, 1991). Although this may be the most efficient way to proceed - since it allows the privatization to proceed quite quickly - - it is usually politically risky.

When public firms are sold at a low price the authorities are usually bound to be accused of "giving away" the national patrimony. An alternative procedure is to "clean" the firms to be privatized from bad debt before they are offered to the public. A potential problem with this approach is that the public enterprises bad debts are sometimes transferred to the Central Bank, transforming a fiscal deficit into a quasi-fiscal deficit. 19 If, Indeed, as part of the pre-privatization strategy the authorities decide to free public firms of bad loans, a more effective procedure is to transfer them to a specially created institution or holding company that will only have losses. The

${ }^{18}$ In fact, for years and years IMF stabilization programs have included the elimination of subsidies as one of their most important components (see Edwards (1989)).

19 This happened, for example, In Chile during the second round of privatization in 1985-87. See, for example, Luders (1990). 
government, then, w11 have to finance these losses from its general budget. In this way the system greatly gains in transparency and efficiency.

\section{3 Deindexing Labor and Other Markets}

A common characteristic of very high (as opposed to hyper) inflations episodes is that the system acquires considerable inertia. This usually happens through (Implicit or explicit) indexation and the existence of staggered contracts. The existence of these inertial forces (partially) explains why, even in cases when the monetary overhang and the monetization of the fiscal deficit are eliminated, inflation takes a long time to subside. An important initial step, then, in stabilization programs is to deindex the economy, trying to transform agents behavior from being backward-looking to being forward-looking. A successful broad deindexation process will affect not only wages, but also debt and other contracts. However, maintaining a tax system that is resilient to inflation has been an Important component of successful programs. In both Poland and Yugoslavia the deindexation of wages has been an important component of the initial stabilization package. 20

The deindexation of the labor market would also play an important role in providing much needed flexibility to the labor market during the adjustment period that follows the freeing of prices and the implementation of other reforms such as the opening up of international trade. In fact, it is well-known that an important prerequisite for reducing the unemployment costs of trade liberalization structural reforms is to eliminate most wage rigidities including indexation. The reason for this is that in countries with labor intensive exports, a trade liberalization will, under most

${ }^{20}$ On a series of interesting case studies on attempts to deindex during a stabilization program see Williamson (1985). 
circumstances, result in a reduction in the real wage rate in the short run. Over the longer-run, however, as investment in new equipment takes place, wages will tend to increase until in the new equilibrium the new wages will tend to exceed those prevalling before the reforms. 21 If, however, the real wage is not allowed to decline in the short run, a significant increase in unemployment will take place. In that regard it is highly likely that if wages had not been deindexed the increase in unemployment in Poland (from 0 In 1989 to approximately 5.5 in September 1990), would have been even larger.

\section{4 An Exchange Rate Anchor?}

In both Poland and Yugoslavia, after the Initial maxi-devaluation and the establishment of partial convertibllity, the nominal exchange rate was fixed as a way to provide an anchor for the price system. Although exchange rate based stabllizations have had a long history, they remain controvers-

1al. Many authors see a serlous danger of real exchange rate overvaluation assoclated with these policies. This could indeed be the case if after the inftial devaluation and the pegging of the nominal exchange rate, Inflation continues to go on at a pace significantly higher than world inflation. In this case domestic goods would quickly lose international competitiveness and a serious balance of payments situation could evolve.

The most common cause for real exchange rate overvaluation in exchange rate based stablization programs is that the pegging of the nominal exchange rate is mainly not accompanied by the required correction in the fundamental determinants of inflation such as the fiscal deficit and money

21 This statement is based on the plausible assumption that in the short run capital is sector-specific. Only slowly through time can capital be reallocated across sectors. On these issues see Edwards (1988). 
creation. However, even if the adequate fiscal and monetary policies are put in place, there is still a serious risk of overvaluation if the economic system exhibits some inertia. This possibility can be illustrated with the following simple model of an econony with partial backward indexation based on Edwards and Edwards (1991):

$$
\begin{aligned}
& \dot{\mathrm{P}}_{t}-\alpha \dot{\mathrm{P}}_{\mathrm{Tt}}+(1-\alpha) \dot{\mathrm{P}}_{\mathrm{N} t} \\
& \dot{\mathrm{P}}_{\mathrm{Tt}}-\dot{\mathrm{E}}_{\mathrm{t}}+\dot{\mathrm{P}}_{\mathrm{T} t}^{\mathrm{t}} \\
& \mathrm{D}^{\mathrm{N}}\left[\left(\mathrm{P}_{\mathrm{N}} / \mathrm{P}_{\mathrm{T}}\right)_{t}, \mathrm{Z}_{\mathrm{t}}\right]-\mathrm{S}^{\mathrm{N}}\left(\left(\mathrm{W} / \mathrm{P}_{\mathrm{N}}\right)_{t}\right) \\
& \dot{\mathrm{W}}_{\mathrm{t}}-\mathrm{k} \dot{\mathrm{P}}_{\mathrm{t}-1}
\end{aligned}
$$

$\dot{\mathrm{P}}_{t}$ is the percentage rate of change of the domestic price level: $\dot{\mathrm{P}}_{\mathrm{Tt}}$ is the percentage rate of change of the price of tradables expressed in domestic currency: $\dot{\mathrm{p}}_{\mathrm{N} t}$ is the rate of change of nontradable goods prices; $\hat{\mathrm{E}}_{t}$ is the rate of devaluation, and $\hat{\mathrm{P}}_{\mathrm{T} t}^{\mathrm{t}}$ is the rate of change of the international price of tradables; $D^{N}$ and $S^{N}$ are the demand and supply functions for nontradable goods; $W$ is the nominal wage rate, and $\hat{W}_{t}$ is its rate of change in perlod $t$; and finally, $z_{t}$ is aggregate real expenditure. $^{22}$ Equation (2) states that the rate of change of the overall price level is a welghted average of the rate of change of tradables and nontradables inflation, with $\alpha$ and $(1-\alpha)$ being the weights. Equation (3) links the domestic price of tradables to the world price via the nominal exchange rate. Equation (4) is the equilibrium condition for the market for nontradable goods. Demand depends negatively on relative prices and positively on aggregate real expenditure. Supply of nontradables, on the other hand, depends negatively on the product wage rate. Equation (5) is

${ }^{22}$ Naturally, this simple representation assumes that the monetary overhang situation has already been solved. 
the rule of wage indexation and states that in every period nominal wages are adjusted in a percentage $k$ of past inflation. If, as was the case in Chile, there is full backward indexation, $k-1$, and $\dot{W}_{t}-\dot{P}_{t-1}$. Under the assumption that as part of the stabllization program the nominal exchange rate is pegged $\left(\dot{E}_{t}-0\right)$, and that aggregate expenditure does not change $\left(\dot{z}_{t}-0\right)$. We obtain the following equation for domestic inflation:

$$
\dot{\mathrm{p}}_{t}-\left(\frac{\alpha \epsilon+\eta}{\eta+\epsilon}\right) \dot{\mathrm{p}}_{t_{t}}+\frac{(1-\alpha) \epsilon k}{\eta+\epsilon} \dot{\mathrm{p}}_{t-1}
$$

when $\eta$ is the price demand elasticity for nontradables (that is, $\eta<0$ ) and where c is the supply elasticity of nontradables with respect to the product wage $(c<0)$. Th1s equation clearly captures the fact that under these circumstances the domestic rate of inflation will exhibit inertial behavior. The 1mportance of this inertial force will not only depend on the extent of indexation $k$ but also on the parameter $(1-\alpha) c /(\eta+c)$. In the case where there is 1008 backward indexation $(k-1)$ the domestic rate of Inflation will eventually converge to the world rate of inflation of tradables $\left(\dot{\mathrm{P}}_{\mathrm{T}_{t}}\right)$.

Defining the real exchange rate (e) in the standard way:

$$
e_{t}=\frac{E_{t} P_{T t}}{P_{t}},
$$

we find that its evolution through time will be given by:

$$
\dot{\mathrm{e}}_{t}-\frac{c(1-\alpha)}{\eta+\epsilon}\left(\hat{\mathrm{P}}_{\mathrm{T} t}-\mathrm{k} \dot{\mathrm{P}}_{t-1}\right) \text {. }
$$

This means, then, that to the extent that the world rate of Inflation $\hat{P}_{\text {Tt }}$ falls short of lagged Inflation multiplied by the coefficient of wage indexation, the real exchange rate will be subject to an appreciation process $\left(\dot{e}_{t}<0\right)$. The higher is $k$, the higher will be the likellihood of 
a real appreciation, and eventually, of overvaluation. 23

During 1990 both the Pollsh and the Yugoslavian economles have experlenced 1mportant real exchange rate appreclations that have slowly, but surely, reduced the degree of competitiveness of their exports. In Yugoslavia this process resulted in the abandonment of the fixed rate in early 1991. In the case of Poland it is difficult, however, to know whether the real exchange rate is approaching the dangerous area of overvaluation where serlous damage to the country's external sector is done. ${ }^{24}$ The reason for this is that given the peculiarities of Central European trade in the past, it is difficult to use historical series to make real exchange rate comparisons. I return to this subject in Section III in 1 ight of the Chilean and Mexican experience.

The rationale for relying on exchange rate based stabllization programs Is based on two interrelated ideas: first, a fixed nominal exchange rate imposes discipline on the monetary and fiscal authoritles as well as on manufactured goods producers, and second, a pegged nominal exchange rate reduces the expectations of inflation. Some recent work on stabilization in advanced nations has argued that the credible adoption of an exchange rate system with limited flexibility such as the exchange rate mechanism of the EMS, will by Itself reduce inflation pressure through a change in Inertial

23 An important feature of this model for understanding some of the potential problems assoclated with the Polish Yugoslavian programs is that to the extent that there are increases in aggregate demand $\left(Z_{t}>0\right)$ fueled by increased transfers from abroad, the forces towards apprectation and, eventually real overvaluation, would increase significantly. In fact, the abandonment of the fixed nominal rate in Yugoslavia after one year was the result of real appreciation fueled by a combination of inertia and increases in aggregate expenditure.

${ }^{24}$ After the revised version of this paper was finished the Zloty was devalued. The Pollsh authorities argued that the reason for this devaluation was the loss in competitiveness suffered by the country. 
forces. 25 The key issue, of course, is whether the unilateral adoption of a fixed rate is indeed credible. If this is not the case the public will speculate against the fixed rate and the Central Bank making the Inflationary situation even more difficult.

Whether a speciflc program based on a pegged exchange rate has credibility 1s, to a large extent, an empirical is sue that will vary from country to country and across historical settings. However, it is still possible to make some general comments on the subject. First, the degree of crediblitty of the pollcy will largely depend on the percelved coherence of the program. If the public sees that there is genulne progress on the fiscal and monetary fronts, and that some agreements between unions and firms are established, the degree of credibility on the sustainability of the flxed exchange rate will increase. Second, credibllity will be much greater if there are institutional constraints that will require the government to maintain its comaltment of a flxed rate, and thus of fiscal discipline. This type of Institutional constraint is present in countries that join the EMS or (to a lesser extent) that have an independent Central Bank, but not necessarily in nations that unilaterally decide to peg their nominal exchange rate, such as Poland and Yugoslavia did in 1990. I'Il return to this issue in greater detail in my discussion of the Chilean and Mexican experiences.

Recently some authors have investigated some of the most important real consequences of stabllization programs based on pegging the nominal exchange rate. In a comparative study of several Latin American eplsodes from the 1960 s through the $1980 \mathrm{~s}, \mathrm{~K} 1 \mathrm{guel}$ and Leviatan (1990) found that most exchange rate based anti-inflatlonary programs have been characterized by both an

\footnotetext{
${ }^{25}$ On these issues see, for example, Glavazz1 and Glovanint (1989).
} 
expansion of real activity in the initial months of the program and by a nontrivial degree of real exchange rate appreciation. Calvo and Vegh (1990) have developed an optimizing model of a swall open economy to formally compare the inflationary and real effects of exchange rate and monetary based stabilization programs. ${ }^{26}$ In a setup with a cash in advance constraint, currency substitution and capital mobllity, they find that a credible exchange rate based stabilization generates an output expansion through the permanent reduction of domestic interest rates. However, if the program lacks credibility the initial expansion of output is followed by an 1mportant recession. They also argue that the less credible the program 1s, the more significant will be the real effects of the stabilization program.

III. Some Latin Amerfcan Lessons for Eastem Europe: Yoney Overhang. Exchange Rate Anchors and Deindexation

Although Chile did not become a full blown soclalist country under President Salvador Allende, the Initial conditions faced by the Chilean free-market reformers (sometimes called the "Chicago boys") were in more than one respect simflar to those encountered in Central and Eastern Europe. A significant repressed inflation had generated a major monetary "overhang", whose elimination some experts estimated would have required a rise in prices of approximately 5008 by mid-1973. 27 In part as a consequence of this the economy was plagued by generalized scarcity, long queues and rampant black markets. The fiscal deficit -. which was fully financed by money creation - - reached 268 of GDP in 1973. Although "officlal" annual Inflation was 7008 in September of 1973, all the avallable evidence

${ }^{26}$ This is done from a different perspective, In Fischer (1986).

${ }^{27}$ See Bardon (1973). Corbo and Solimano (1990) also find that in Chile there was a significant monetary overhang at the end of the Allende period. 
Indicates that the economy st111 faced a major "stock" disequilibrium. A program of nationalization of domestic and forelgn owned firms had resulted in a two-fold increase in public sector value added between 1970 and 1973. As in Poland, unemployment was virtually nonexistent, while labor productivity was rapldly declining.

The main goals of the Chilean economic team in 1973 were to defeat inflation, reestablish external equilibrium and transform the economy from a tightly centralized system Into a market-orlented regime. Although the political systems were very different, there are some remarkable similaritLes between Ch1le's market-orlented economic pollcles and those of Poland and Yugoslavia. (See Table 2 for a synoptic comparison between Chile and Poland's policles.) As in Poland and Yugoslavia, Chile eliminated the vast majority of price controls during the first week of the reforms - more than 3,000 prices were Immediately freed; prices of 39 "necessities", however, remalned under loose control for some time. A very large devaluation (over 908) was used as a way of dealing with the monetary overhang and, as in Poland, partial currency convertibllity (for commerclal transactions) was rapidly established. An external sector trade reform that 1mmediately eliminated all Import 11censes, prohibltions and quotas, and that by 1979 had slashed Import tariffs to a uniform 108 was rapidly enacted. As in Poland the initial reaction to these policies was a dramatic increase in nontraditional exports that had no precedent in history. For example, in 1974 the U.S. dollar value of non-mineral exports 1ncreased 2008 with respect to 1973 .

In Chile the flow macroeconomic disequilibrium was tackled by a simultaneous reduction of government expenditures and an increase in revenues. This was achleved through a sweeping tax reform that, among other 
things, established a 20 value added tax. As a result of these measures, by 1977 the fiscal deficit had virtually disappeared. The combination of a liberalized financial sector, with scores of newly privatized banks and insurance companies, and a restricted macroeconomic policy resulted in very high interest rates.

There are still more similarities. As In Yugoslavia and Poland, the Chilean authorities implemented an "exchange rate based" stabilization, where the fixing of the nominal exchange rate in a context of an economy open to international competition was the cornerstone of the anti-inflatlonary program. Also, as in the recent Eastern European programs, in a further effort to eliminate inflationary pressures, wage indexation was greatly reduced and the labor market was reformed.

In spite of all the efforts to rapidly eliminate inflation. Chile experienced substantial inertia, with price increases crawling down quite slowly. In fact, it took elght years to achleve single digit inflation: in 1981 the rate of inflation was 8.98. Moreover, when this goal was finally achleved, the years with domestic inflation above world inflation had generated a massive overvaluation of the peso that greatly affected the economy's degree of international competitiveness. Exports began to stagnate while Imports, especially of durable goods, boomed. Industrial production fell and a sense that the policy package was losing sustainability began to take over the economy.

In the rest of this section I discuss in some detall some of the most Important specific Chllean lessons on stabllization. In doing this I concentrate on the four issues discussed in the preceding section: (1) the elimination of money overhang: (2) the fiscal deficit and the flow macrodisequilibrium: (3) the indexation of the labor market: and (4) the use 
of the nominal exchange rate as an anchor. When dealing with this last Important 1ssue I formally compare the effects of the Chilean and Mexican exchange rate based stabilization programs.

\section{III.1 Money Overhang and the Indtial Stabllization Program}

The economic policles of Dr. Salvador Allende during 1970-73 generated a classical situation of repressed inflation. 28 The combination of rapid Increases in the quantity of money coupled with stringent price controls resulted in growing scarcity of goods, de facto rationing and a rapidly growing black market. As a result of this disequilibrium in mid-1973 the black market premlum for forelgn exchange surpassed 3000 (see F1gure 2). Former Unldad Popular Minister Serglo Bltar has described the situation as follows:

The black or parallel market emerged in Chile in 1972, and became increasingly important during 1973. Economic disequilibria grew more rapidly than the new control mechanisms ... The excess of aggregate demand and ... monetary expansion increased during the first half of 1972. ... Relative price distortions also fueled the black market, ... [especially] in the textlle and construction sectors ...

(B1tar, 1979, pp. 196-97)

Although during the last months of the Allende presidency the officlal rate of inflation had reached 15 per month, at the time of the coup (September 1973), there was st1ll a substantial monetary overhang. Bardon (1973), for example, estimated In August of 1973 that in order to eliminate the overhang the price level had to Increase (Jump) between 400 and 560 percent. More recently, Corbo and Sollmano (1990) have estimated, on the basis of demand for money regressions, that in the third quarter of 1973 the magnitude of the monetary overhang was approximately equal to 50 of total

${ }^{28}$ For an extraordinary insiders account of the economic policies of Allende, see Bltar (1979). For a recent analysis of the conduct of macroeconomic pollcy during this perlod see Dornbusch and Edwards (1989). See also Larrain and Meller (1991). 
money demand. Table 3 , which shows the evolution of the real quantity of money in Chile in the 1965-78 period, clearly shows the dramatic increase in M/Py experienced during the Allende years of 1971-73 and 1ts precipitous fall immediately following the coup.

One of the most 1mportant priorities of the military economic team was to eliminate the monetary overhang and black markets. Interestingly enough at that time there was no whatsoever on the possibllity of a monetary reform; from the very beginning the decision was made to free almost all prices and to let the fump in the price level take care of the overhang. This was, In fact, done at the same time as a 908 devaluation was engineered and (partial) convertibllity for commercial transactions was established. As a result of this policy, prices increased in October of 1973 by almost 908 (see Table 4).

The strategy followed during the first weeks of milltary rule were clearly stated by the "super" Minister Jorge Cauas in a 1974 speech:

The generalized control of prices had created two serlous problems ... [1] the proliferation of black markets, ... and ... various rationing mechanisms. ... (And 2), a totally arbitrary price structure. ... The strategy used to correct these disequilibria consisted in creating a free price system.

(Mendez, 1979, p. 92, emphas1s added)

The Immediate effect of this measure was the overnight disappearance of black markets and rationing, followed by a precipitous fall in the premium In the parallel market for forelgn exchange (F1gure 2). As transactions moved back Into the "overground" economy, tax collection rapidly Increased providing a partial alleviation to the fiscal deficlt, which in 1973 had reached the extraordinarlly high level of 23 of GDP. All of this, of course, bears a remarkable similarity to the recent Eastern European episodes. 
The freeing of prices and the devaluation of the nominal exchange rate was rapidly supplemented with a battery of other measures. Subsidies to public sector firms were eliminated, public employment was cut, wages in the public sector were reduced in real terms, and a process of privatization, that resulted in the transfer of 251 firms to the private sector in 1974 alone, was initiated. 29 The process of trade liberalization and financial reform were also started. During 1974 most quantitative restrictions on Imports, Including a 10,000 percent prior deposit, were eliminated, and an initial round of tariff reduction took place.

An Important component of the early policies was the attempt to shift the focus of wage setting from backward looking to forward looking. Formal wage adjustments based on past Inflation, which during the Unidad Popular government had been applied with increasing frequency, were eliminated in the rest of 1973, and were replaced by a bonus system that amounted to granting two additional monthly salaries during late 1973. During 1974 there were four obligatory (economy-wide) wage adjustments for an accumulated total of 2648. During the same period the accumulated rate of inflation was 3478 . In terms of exchange rate policy, after the initial devaluation a crawling peg system almed at maintaining the real exchange rate relatively constant was enacted. 30

As a result of the initial public sector measures the fiscal deficit was reduced by more than one half in 1974. As can be seen from Table S, most of this fiscal adjustment came from a reduction in expenditure. In spite of this progress, at the end of 1974 the fiscal deficit still stood at

${ }^{29}$ of these, 202 were actually returned to their owners and 49 were sold. See Chapter 4 of Edwards and Edwards (1991) for deta1ls.

${ }^{30}$ For detalls see Edwards and Edwards (1991). 
almost 118 of GDP.

Although the strategy chosen by the military advisors to eliminate the money overhang succeeded in achieving 1ts objective, it did so at a large cost. The combination of an enormously large price jump, a major devaluation, and price freedom in a country with a 40-year tradition of price controls, generated substantial expectations of further inflation in the private sector. In a perceptive article, Ramos (1977) has argued that as soon as firms had the possibility (for the first time in many years) to freely set prices, they decided to ant1cipate expected future cost increases by ralsing prices by more than what fundamentals dictated. Additionally, in late 1973 the state of uncertainty was such that no one was sure whether (or when) the gevernment would return to the decades-long tradition of fixing prices. Not surprisingly, then, firms - which at the time faced very 11ttle forelgn competition, since the trade sector had not yet been opened - decided to face this uncertainty by over-adjusting their prices.

These expectations of high and rapid inflation were validated during the first quarter of 1974 when the government mandated a wage adjustment of 60 and Implemented a devaluation with respect to the U.S. dollar of 41. The accumulated rate of inflation during that quarter was $47 \mathrm{t}^{31}$ From that point onwards, Chilean inflation exhiblted a significant degree of Inertia that was mainly determined by expectations, and their validation through both exchange rate devaluations and money creation. ${ }^{32}$ There is

${ }^{31}$ See Ramos (1977).

${ }^{32}$ It is interesting to note that computations of the steady state rate of inflation justifiable by the fiscal deficit was significantly lower in every one of the initial years than the actual inflation. In 1974, for example, the "Justifled" rate of inflation was between 200-250 while actual inflation exceeded 370. The difference between these two figures can (partially) be explained by inertial forces. In 1978 the government decided to dramatically face expectations through the adoption of an exchange rate 
11ttle doubt that the unleashing of these substantial and chaotic expectations of Inflation in the aftermath of the price fump of October 1973, were largely responsible for the extraordinarily long time it took for the Chilean inflation rate to subside. This slow speed of stabilization is particularly puzzling once it is recognized that for all practical purposes by 1977 the fiscal deficit problem had been completely solved. It is not possible to know what would have happened if a monetary reform - accompanled, or shortly followed by the freeing of prices -- would have been Implemented in 1973. One can only speculate that in this case inflationary expectations would have been lower, and that possibly the transition to lower more stable Inflation would have been more rapid.

\section{III.2 Iax Reform. The Fiscal Deficit and Inflation}

In early 1975 a sweeping tax reform was implemented in Chile. The principal features of this reform include the replacement of a cascade sales tax with a flat rate value added tax at a 208 rate; a full indexation of the tax system; an elimination of the remaining tax exemptions and subsidies; a unification of the corporation and non-corporation income taxes into a flat business tax; and the integration of the personal and business income taxes. 33 As may be seen in Table 5 the combination of Increased tax revenues and reduced government expenditure rapidly affected the fiscal deficit.

The fiscal reform of 1975 was part of a broader stabilization program almed at "finally defeating inflation". This program was based largely on traditional monetarist views regarding inflation in closed economies and

based stablization that culminated with the fixing of the peso to the U.S. dollar in June of 1979. The most important characteristics of this program are analyzed in subsection III. 2 below.

${ }^{33}$ See Edwards and Edwards (1991) for greater detalls on the reform. 
considered that woney creation to finance the fiscal deficlt was the basic and most fundamental cause of inflation. Consequently, this stabllization program did not consider using the exchange rate as an anti-inflationary tool. In fact it was decided to malntain a crawling peg exchange rate system that consisted of periodically adjusting the nominal exchange rate at approximately the same rate as lagged inflation.

In June of 1976, as a means to break Inflationary expectations, the government revalued the peso by 10 with respect to the U.S. dollar. Following this revaluation the process of mint-devaluations, where the nominal exchange rate (relative to the U.S. dollar) was adjusted at approximately the same rate as past Inflation, was resumed. In March 1977 , in order to further break expectations, the nominal exchange rate was again revalued by 108 . Once again, this appreciation was followed by periodic devaluations that tried to compensate firms for the loss of competitiveness generated by the tariff reduction process. Although in 1976 and 1977 some progress was made in the battle against inflation, by late 1977 inflation was still very high in absolute levels - 878 .

The revaluation of the peso of 1976 and 1977 marked the first steps toward a major change in the Chilean stabilization strategy and in the authorities' concept of the role of macroeconomic policy. In late 1977. with the rate of inflation standing at a yearly level of 848 , the government authorities argued that given the Increasing open character of the Chilean economy, traditional anti-inflationary programs based on closed economy premises were becoming clearly ineffective. It was then pointed out that a drastic change in the orientation of the stabilization policy was required to make further progress against inflation. In early 1978 Chilean stabilization efforts moved from being a fiscal-based to exchange rate-based. I 
discuss some important aspects of this policy, including its credibility, in subsection III.4.

\section{3 Labor Markets and Indexation}

In the labor markets front the government early-on tried to incorporate some corrective forces. 34 The automatic wage adjustment due in october 1973 was postponed unt1l January of 1974. During that year an effort to provide forward-looking wage adjustment was instituted. This resulted in mandated wage increases below the accumulated rate of inflation. As a result of this, in 1976 real (average) wages were 168 below their 1970 level and 30 below the peak year of 1971. Starting in July of 1977, however, a one-hundred percent plus backward indexation mechanism was put into place. This procedure required that all wages (private and public sector) be revised four times a year according to accumulated past inflation. As inflation was (slowly) declining during this period, this backward looking procedure assured that wages would automatically increase in real terms. Table 6 contains detalled information on the exact dates and magnitudes of wage adjustments.

Not only were wages fully indexed by 1976, but most other contracts also included indexation clauses. Many transactions were denominated in dollars, and with the exception of 30-day CDs all financial transactions were subject to inflation adjustment. There is little doubt that the rapid reincorporation of 100 backward indexation to Chile's economic folklore can partially account for the slow rate at which inflation was reduced.

${ }^{34} \mathrm{~A}$ crucial element in labor market developments during this period is the dismantling of the Chilean labor movement. For political reasons the immense majority of union leaders were persecuted. Union activities were reduced to mere symbolism. 


\section{III.4 Anchoring the System Through the Nominal Exchange Rate}

In February 1978 the administration of the exchange rate completely took over as the most important anti-inflationary tool. At that time a novel policy of preannouncing a declining rate of devaluation for a fairly long perlod of time (up to a year) was introduced as a way of further reducing the rate of inflation. This system, popularly known as the tablita. deliberately set the starting declining rate of devaluation at a lower rate than ongoing inflation. With the trade reform having virtually eliminated the most important trade barriers, 1t was expected that this system of preannounced devaluations would have two important effects on inflation. First, it was thought that it would channel inflationary expectations downward. Second, and more 1mportant, it was expected that the system would work in a way simflar to a textbook-type fixed exchange rate reglme, Imposing price discipline into the economy. It was, in fact, thought that domestic Inflation would rapidly converge to the level of world inflation plus the rate of devaluation of the peso.

In June 1979, with Inflation standing at an annual rate of 348 , the government put an end to the system of a preannounced declining rate of devaluation and fixed the exchange rate at 39 pesos per dollar. It was expected that this move to a fixed rate would reinforce and accelerate the purchasing power parity type convergence of domestic to world inflation.

When the tablita was adopted in early 1978, and again when the peso was pegged to the dollar in June of 1979 , it was decided not to alter the wage Indexation mechanism. Paradoxically then, whlle the authorities expected price setters and other agents to form forward-looking expectations, they maintained a crucial market linked to a rigidly mechanical backward indexation regime. This decision resulted in the maintenance of an important 
component of the inertial forces in the system. 35

\section{III.4.1 Exchange Rate Pegging and Real Exchange Rate Overvaluation}

Contrary to what was expected by the architects of the open economy stablilzation plan, after the exchange rate was flxed in mid-1979, the domestic rate of inflation did not rapidly converge to its world counterpart. Table 7 contains data for 1978-83 on the behavior of the rate of nominal devaluation with respect to the U.S. dollar, of two measures of U.S. inflation, and of the Chilean rate of inflation. In fact, the use of the exchange rate as a stablifation tool helped generate a steady real appreciation, or real overvaluation, of the peso, which, among other things. greatly hurt the degree of competitiveness of firms producing goods in the tradable sector, including nontraditional exports.

Figure 3 shows the evolution of Chile's (bilateral) real exchange rate from 1963 through 1983. Three things stand out from this figure. First. following the fixing of the nominal exchange rate in mid-1979, the RER experienced a sustained real appreciation. Second, when the rate was pegged (and even when the tablita was first adopted in 1978), the RER was relatively low (appreciated) with respect to 1ts 1975-76 levels. This means that there wasn't much of a cushion for the exchange rate to fall, without generating an overvaluation, during the transition to price stability. This, in fact, contrasts with the Mexican experience where prior to embarking on the exchange rate preannouncement program and the Solidarity Pact, the real

35 Besides the adoption of a fixed exchange rate regime, another important development took place during 1979. Steps toward the liberalization of capital flows were taken, when in June of that year commercial banks were allowed to greatly increase their ratio of foreign liablifies to equity. This relaxation of capital inflows resulted in massive borrowing from abroad and paved the way to Chile's debt crisis. I have argued in Edwards (1985) that the massive inflow of forelgn capital was one of the fundamental causes of real exchange rate overvaluation in Chile. 
exchange rate was undervalued. ${ }^{36}$ As a result of this, the subsequent real exchange rate appreciation observed in Mexico has not resulted until this time in a situation of real exchange rate overvaluation.

The third interesting characteristic of Figure 3 is that there is a clear structural break in the real exchange rate behavior in Chile.

Throughout 1974-84, In spite of broad fluctuations, the real exchange rate was at all times significantly higher than at any time during the previous 10 years. Two main "real" events that greatly affected the behavior of "fundamentals" are behind the major real depreclation that took place between 1965-73 and 1979: First, there was a drastic liberallzation of International trade, which eliminated all quantitative restrictions and reduced Import tariffs from an average of more than 1008 to a uniform 10 . level (Edwards and Cox-Edwards, 1987). Second, there was a steep, and apparently permanent, deterioration of Chile's terms of trade; during 1975 79 the average real price of Chlle's main export, copper, was 418 below its 1965-73 average.

An Important aspect of exchange rate based programs refers to the need to monitor RER movements in order to assess whether situations of overvaluation are emerging. This, however, is not an easy task. As the fundamental determinants of the equilibrium real exchange rate changes, as has been the case in Poland and Yugoslavia, it becomes exceedingly difflcult to know with any degree of certalnty whether the RER is moving closer to an overvaluation situation. Under these clrcumstances it becomes extremely Important to monitor very closely developments in the external sector, in order to capture early on any possible signs of overvaluation. In the cases of Chile

${ }^{36}$ On the Mexican stabilization package see Beristain and Trigueros (1990). On a discussion of the evolution of the real exchange rate in Mexico see Edwards (1990). 
and Argentina, in the late 1970 s the abundance of forelgn capital made the evaluation of RER conditions even more difficult, since many of the superficlal signs of overvaluation such as a loss in international reserves and a black market premium were not present. ${ }^{37}$ This situation is indeed a possible danger in Eastern Europe where temporary substantial increases in capital inflows may provide a false sense of boom, hiding potentially dangerous situations of overvaluation.

The steady process of real overvaluation of the peso since the pegging of the peso greatly hurt the performance of noncopper exports. In 1981 the dollar value of nontraditional exports dropped by 158 , while traditional noncopper exports declined by 168. In fact, for those firms in the Corbo and Sanchez (1985) study the overvaluation of the peso was one of the most severe blows recelved throughout the first ten years of the experiment with market-orlented pollcies.

Although at this point it is too early to know whether the recent real appreciations in Poland is moving this country into an overvaluation situation, it is clear that this is a potentially very serlous problem. The economic history of Latin America has clearly shown that overvaluation, with all Its concomitant effects, Including the Imposition of controls, is one of the most dangerous and serlous economic problems.

III.4.2 Exchange Rate Anchors and Credib111ty: A Comparison Between Chile and Mexico

One of the goals of adopting a preannounced rate of devaluation (which could be zero), as in the recent cases of Poland and Yugoslavia in a stabilization program is to alter the public's expectations. Indeed, if the

${ }^{37}$ In principle, temporary increases in capital inflows will result in real exchange rate overvaluation. See Edwards (1989) for a theoretical model and some empirical evidence. 
adoption of a nominal exchange rate rule is credible and the private sector believes that the predetermined nominal rate will 1mpose (or assure) discipline, It will tend to alter its behavior. Ideally, in an economy suffering from significant inertial forces a credible adoption of an exchange rate rule will alter the process of expectations formation from being backwardlooking to being forward-looking. This means that, with other things given, the implementation of a credible exchange rate based stabilization program w1ll reduce the degree of persistance bullt into the inflation process. Contracts, under a credible exchange rate pegging will take into account the change in the exchange rate regime, and this change in behavior will then be reflected in the data on price changes.

A potenitally fruitful line of attack for empirically analyzing the degree of credibility of exchange rate based programs is to investigate if. once the exchange rate rule is adopted, the degree of inertia of inflation was indeed reduced. Formally this can be done by estimating an equation of the following form:

$$
\pi_{t}-a_{0}+a_{1} \pi_{t-1}+a_{2}\left(D \pi_{t-1}\right)+\Sigma b_{j} x_{j t-k}+u_{t}
$$

where $\pi_{t}$ is the rate of inflation in period $t, D$ is a dummy variable that takes the value of 1 during the perlod when the exchange rate based program is in effect, and where the $x_{j}$ 's are other determinants of inflation. In this equation the coefficient $a_{1}$ captures the degree of inertia of the inflationary process before the exchange rate based program and the coefficient $\left(a_{1}+a_{2}\right)$ is our measure of persistence once the exchange rate anchor is used. Under a credible program, then, we would expect the $a_{2}$ to be significantly negative. A zero value, or even worse a positive value of $a_{2}$, would suggest that the program lacked credibility and that it falled to alter the public's expectations and perception of the system's dynamics. 
A number of variations of equation (9) were estimated using quarterly data for Chile. In these estimates two alternative dumby variables were used: the first one (D1) took a value of one between the second quarter of 1978, when the program of preannouncing the rate of devaluation was first Implemented, and the first quarter of 1982. In the second case (D2) the dummy variable took a value of one between the third quarter of 1979 and the f1rst quarter of 1982. That 1s, D2 covers only the perlod when the nominal exchange was strictly fixed. With respect to the other determinants of Inflation (the $x_{j}$ in equation $(9)$ ), current and lagged values of a number of varlables were considered including the rate of devaluation, the rate of growth of domestic credit and the rate of growth of money. Although most equations were estimated for the period comprised between the first quarter of 1974 and the first quarter of 1982 .. that 1s, the last quarter of a fixed exchange rate -. a number of other time perlods were also considered.

In every regression run the coefficlent of $D \pi_{t-1}$ turned out to be positive (although statistically not significantly different from zero). Indicating that the adoption of the exchange rate rule did not alter the degree of inflationary inertia in the system. The following is an example of the type of result obtained (t-statistics in parentheses): ${ }^{38}$

$$
\begin{aligned}
& \pi_{t}=\underset{(-0.869)}{-0.031}+\underset{(8.923)}{0.754} \pi_{t-1}+\underset{(0.669)}{0.249 \mathrm{D} 2 \pi_{t-1}}+\underset{(1.352)}{0.123 \mathrm{DEV}} \mathrm{CV}_{t} \\
& +\underset{(3.001)}{0.076 \mathrm{DEV}_{t-1}}-\underset{(-0.990)}{0.133 \mathrm{GM}_{t}}+\underset{(2.255)}{0.266 \mathrm{GM}_{t-1}} \\
& \bar{R}^{2}-0.965 \\
& \text { Durbin's h }-0.289 \\
& \text { D.W. }-1.910 \\
& \text { Per1od: } 74 Q 1-82 Q 1
\end{aligned}
$$

${ }^{38}$ This equation was estimated using ols. When instrumental variables were used the results were very similar. 
where DEV is the rate of devaluation and where GM is the rate of growth of $M 1$.

In order to further test whether the adoption of the flxed exchange rate in June of 1979 had an effect on the Inflation process, a number of tests on the structural stability of inflation equations of the type of (9) were performed. If, Indeed the shift from an accomodating adjustable exchange rate reglme to a rigldly predetermined one is credible, it would be expected that the inflation equation would capture a change in regime. However, these stabllity tests were supportive of the dummy variable results reported prevlously, and showed no structural break in the inflation equation. For example, in the case of equation (10) the Chi-square statistic for structural stablitty had a value of $x^{2}(6)-2.23$. Indicating that there is no evidence of a change in the inflationary regime in mid-1979.

The above evidence, then, suggests that the adoption of a predetermined exchange rate in Chile was not assoclated with a change in the nature of the inflationary process that one expects from a credible policy. ${ }^{39}$ In particular, expectations and contract practices (e.g., Indexation) do not seem to have been affected in a signiflcant way. Th1s, of course, was particularly true for the case of wage contracts which largely remalned being backward Indexed to 1008 of past inflation. As a consequence of this, the degree of inflationary inertia remained basically unchanged after the adoption of the exchange rate based program.

Equations of the type of (9) were also estlmated for Mexico. The Mexican program differs from the Chllean case in a very Important respect:

${ }^{39}$ Th1s, of course, does not mean that the flxing of the exchange rate did not have some effect on Inflation. Naturally, to the extent that devaluation enters the inflation equation, a lower DEV will generate a lower $r$. 
while in Chile the stabilization program was based solely on fiscal restraint and a predetermined (and then fixed) nominal exchange rate, in the case of Mexico Incomes policles became a central element of the ant Inflationary package, supplementing the exchange rate rule and the fiscal adjustment. Indeed in late 1987 with the establishment of the Pacto de Solidaridad, unions, entrepreneurs and the government worked out a politically and economically feasible plan for defeating inflation: price and wage guidelines became important elements of this program. 40

The key question, then, is whether a program which combines the use of the exchange rate as an anchor with incomes policies is more credible .. and thus is able to alter the dynamics of inflation -. than a program that relles exclusively on the exchange rate anchor. 41 In order to investigate this a number of equations based on (9) were estimated using quarterly data for Mexico for the period 1979-90. As in the Chilean regressions the dummy variable was defined for two alternative perlods: D3 takes a value of one between the second quarter of 1988 and the second quarter of 1990, while D4 takes a value of 1 from the first quarter of 1989 (when the Pacto was first renewed) and the second quarter of 1990.

Contrary to the case of Chile, in every equation estimated for Mexico the coefficlent of $D \pi_{t-1}$ turned out to be significantly negative. Indicating that the adoption of the preannounced exchange rate system, and the other policies in the Pacto, were credible significantly changing the dynamics of inflation. The following equation illustrates the type of results obtalned:

${ }^{40}$ See Beristain and Trigueros (1990) for a useful description.

41 The Implicit assumption is that in both cases the fiscal side has been corrected. This was indeed the case both in Chile and Mexico. 


$$
\begin{aligned}
& \pi_{t}-\underset{(-0.417)}{0.002}+\underset{(20.778)}{0.845} \pi_{t-1}-\underset{(-4.222)}{0.197} \mathrm{D} 3 \pi_{t-1}+\underset{(3.551)}{0.077 \mathrm{DEV}_{t}} \\
& +\underset{(2.233)}{0.059 \mathrm{DEV}_{\mathrm{t}-1}}+\underset{(1.476)}{0.046 \mathrm{GM}_{\mathrm{t}}}+\underset{(1.852)}{0.059 \mathrm{GM}_{\mathrm{t}-1}} \\
& \text { (2.233) } \quad \begin{array}{llll} 
& (1.476) \quad(1.852) \quad & R^{2}-0.964
\end{array} \\
& \text { Durbin's h }-1.321 \\
& \text { D.W. }-1.621 \\
& \text { Perlod: 79Q1-90Q1 }
\end{aligned}
$$

The estimated autoregressive term for the Pacte period is equal to 0.648 , only 758 of 1 ts value during the rest of the period. Although it is not possible to make generalizations at this point, these contrasting results between ChIle and Mexico are quite suggestive, Indicating that the adoption of an exchange rate rule on its own need not alter the dynamics of Inflation, if it is not supplemented by a battery of accomanying income policies that provide (politically acceptable) guidelines to prices and wages.

\section{Concluding Remarks}

In this paper I have analyzed some of the most important stabllization pollcy problems faced by the USSR and the Eastern European nations: (a) how to deal with the monetary overhang; (b) how to face the fiscal deficit problems; (c) the deindexation issue; and (d) the question of exchange rate anchors. With respect to each of these areas I have discussed some lessons stemming from the Latin American experience with stabllization and anti-inflationary policles. Although in dolng this I have focused mostly on the case of Chile -. a country whose initial economle conditions somewhat resembled those encountered In Eastern Europe -. I have also dealt with the Mexican experience.

The most Important conclusions of this study can be summarized as follows: 
(1) The reliance on a major price level fump to eliminate the monetary overhang in Chile in October of 1973 proved to be costly. Expectations of inflation became high and chaotic, with firms and other agents adjusting their prices in anticipacion of expected further inflation. These expectations, plus the rapld full indexation of the economy, were translated into a system with a high degree of Inertia, and thus in an extremely long path towards price stab1lity.

It is not possible to know what would have happened if an alternative pollcy had been followed. One can only speculate that some type of monetary reform - possibly one that would have based on combined currency blocking -. would have resulted in a smoother and less traumatic transition. ${ }^{42}$ Under this alternative policy the monetary reform would have been fmmediately followed by a relaxation of (most) prices and a devaluation. The freeing of prices would have allowed a correction in relative price distortions but presumably would not have resulted in the type of traumatic fump in the price level that was, in fact, observed. Also, after the monetary reform the required discreet devaluation would have been smaller than what was actually observed.

(2) There is no doubt that fiscal adjustment is a crucial requirement for achleving stabllity. An Important component of this adjustment is to create a tax system that is not vulnerable to inflation itself. The sophistlcated Inflation adjustment clauses introduced to the Chilean tax system in late 1974 greatiy helped that country to ellminate the public sector Imbalances. The creation of this type of system in Eastern Europe seems to be an important element for achleving a stable macroeconomic environment.

42 Arguably the blocked funds could have been used to create some long maturity instruments in the emerging financlal market. 
(3) In successful experiences the efforts to delndex the labor market -. delinking wage increases from past inflation -. have been malntalned throughout the stablization program. In Chile, the return to full backward looking Indexation in late 1976 added considerable inertia to the Inflationary process. Whether a delndexation program will indeed be feasible will depend on political consensus. Whether this type of policy is politically possible in Eastern Europe is not yet clear.

(4) The adoption of an exchange rate based stabilization program, where the nominal exchange rate is elther pegged, or 1 ts rate of change is predetermined at a rate below ongolng inflation, carries a serlous danger of provoking a major overvaluation. This can even happen if the fiscal deficit is fully uncler control as in the case of chile. Some countries, such as Mexico, have dealt with this problem by starting the stabilization program at a point that is one of undervaluation as in Mexico in 1988.

(5) The most 1mportant goal of the adoption of a predetermined nominal exchange rate as part of a stabllization program is to alter the dynamics of the Inflationary process. More specifically, a credible adoption of an exchange rate rule will reduce the degree of Inertia in the system. An empirical comparison between the ChIlean and Mexican cases show that while In the former the adoption of the exchange rate rule did not affect the inertial forces bullt in the system, in Mexico the degree of persistence in inflation was significantly reduced. The main difference in these two experiences is that in Mexico the exchange rate rule was supplemented with other incomes policies. 


\section{ACKNOWLEDGEMENTS}

University of California, Los Angeles, The National Bureau of Economic Research, and Institute for Policy Reform. Comments welcome. First draft: December, 1990; revised: February, 1991, March, 1991, May, 1991 and August, 1991. This is a revised version of a paper presented at the IRIS-IPR conference on Eastern European Reform, Prague, March 24-26, 1991. A previous version of this paper was presented at the American Economic Association Annual Meetings, Washington, DC, December 27-30, 1990. I am indebted to my discussants at the AEA meetings for helpful comments. I am grateful to Geoff Carliner, Julius Santaella and Chris Clague for their comments. Once again I am indebted to Mike Savastano for helpful discussions. Support from the Institute for Policy Reform is gratefully acknowledged. 
Banco Central de Chile, Boletin Mensual. 1984.

Bardón. A., "Situaction Monetarla e Inflaction," Universidad de Chile, 1973.

Beristain, J., and I. Trigueros, "Mex1co's Stabilization Program," In J.

W11lamson (ed.), Latin American Economic Adjustment. 1990.

Bitar, S., La Polftica Economica de la Unidad Popular. S1glo XX1, 1979.

Calvo, G., and C. Vegh, "Credibllity and the Dynamics of Stabilization

Pollcy: A Basic Framework," IMF, 1990.

Corbo, V., and R. Sanchez, "How Firms Adjusted to the Reforms in Chile." World Bank, 1985.

, and A. Solimano, "ChIle's Experience With Stabllization

Revisited," World Bank, 1990.

Cortazar, R., and J. Marshall, "Indlce de Preclos al Consumidor en Chile," ms., CPEPLAN, Sant1ago, Ch1le, 1980.

Covicell1, F., and R. Rocha, "Stabllization Programs in Eastern Europe:

Poland and Yugoslavia," World Bank, 1990.

de Castro, S. "Exposinón de la Haclenda Pública," Ministerlode Hacienda, Santlago de Chile, 1981.

Dornbusch, R., and S. Edwards, "Macroeconom1c Populism in Latin America,"

NBER Working Paper \#2986, 1989.

, and H. Wolf, "Monetary Overhang and Reforms in the 1940s," NBER

Work1ng Paper 3456, 1990.

Edwards, S., "Stabllization with Liberalization: An Evaluation of Ten

Years of Chile's Experinent With Free Market Policles - 1973-83,"

Economic Development and Cultural Change. 33 (Jan. 1985). 
, Terms of Trade, Tariffs, and Labor Market Adjustment in

Developing Countries," World Bank, 1988.

- Real Exchange Rates. Devaluation and Adjustment, MIT Press,

$1989 a$.

- The International Monetary Fund and the Developing Countries:

A Critical Evaluation," in Carnegle-Rochester Public Policy Series,

North-Holland Publishing Co., $1989 \mathrm{~b}$.

- "Mexico and Argentina Comments," in J. Williamson (ed.), Latin

American Adfustment, IIE, 1990.

Edwards, S., and A.Cox-Edwards, Monetarism and Liberslization: The ChIlean

Experfment, Cambridge, MA: Ballinger, 1986; revised ed., University of Chicago Fress, 1991.

Fischer, S., "Issues in Medium-Term Macroeconomic Adjustment," World Bank Research Observer, 1986.

Giavazzi, F., and A. Giovanini, Limiting Exchange Rate Flexibllity: The

European Monetary System, Cambridge, MA: MIT Press, 1989.

Hinds, M., "Issues in the Introduction of Market Forces in Esstern European Socialist Economies," World Bank, 1990.

Kiguel, M. and M. Liviatan, "The Business Cycle Associated With Exchange Rate Based Stabilizations," World Bank, 1990.

Larrain, F., and P. Meller, "Populism in Chile, 1970-1973," in R. Dornbusch and S. Edwards (ed.). The Macroeconomics of Populism in Latin America,

University of Chicago Press, forthcoming, 1991.

Lipton, D., and J. Sachs, "Creating a Market Economy in Eastern Europe:

The Case of Poland," Brookings Papers, 1990.

Luders, R., "The Privatization of the Chilean Economy," mimeo, UCLA, 1990. 
Mckinnon, R., "Stabllizing the Ruble: The Problem of Internal Currency Convertibllity," mimeo, Stanford Univers1ty, 1990.

Mendez, J.C., Chllean Economlc Policy, Santlago, 1980.

Nordhaus, W.D., "Soviet Economic Reform: The Longest Road," Brookings Paper, 1990.

Ramos, J., "La Economia de la Hiperestaflación en Chlle," Cuadernos de conomia, 1977.

Rocha, R., "Stabllization Programs in Yugoslavia," World Bank, 1990.

w1lliamson, J., Indexation and Inflation, IIE, 1989.

Yanez, J., "Una Correccion del Indice de Prenios al Consumidor Dorcute el Perlods 1971-73," in F. Contreras (ed.), Comentarlos subre la situacton Economica; Santlago: Universidad de Chile, 1978. 
TABLE 1

Economic Conditions In The USSR And Eastern Europe In 1989

\begin{tabular}{|c|c|c|}
\hline $\begin{array}{l}\text { Estimated } \\
\text { Real GDP } \\
(1986-100)\end{array}$ & $\begin{array}{c}\text { Growth In } \\
\text { Industrial } \\
\text { Output } \\
\text { in } 1989^{\circ} \\
\end{array}$ & $\begin{array}{c}\text { Inflation } \\
\text { Rate in } \\
1989 \\
\end{array}$ \\
\hline 99.8 & 0.08 & 11.48 \\
\hline 104.0 & 0.08 & 1.88 \\
\hline 101.4 & -3.68 & 16.98 \\
\hline 97.9 & -4.28 & 640.08 \\
\hline 99.5 & n.a. & n.a. \\
\hline 105.5 & 0.08 & 5.78 \\
\hline 98.4 & -1.08 & 2795.08 \\
\hline
\end{tabular}

\footnotetext{
${ }^{a}$ Refers to adjust (as opposed to official) data.

Source: Directorate of Intelligence, Central Intelligence Agency (CIA), 1990.
} 
TABLE 2

Policles for Stabilization and Market-Orlented Reform:

A Comparison Between Chile in the 1970s and Poland in the 1990s

\section{Chile}

A. Price and Wage Rate Pollcles

- More than 3000 prevlously controlled prices were freed in October of 1973. Initially only 30 goods continue to have controlled prices.

- From Oct. 1973 to July 1975 partial and lagged wage Indexation; between July 1975 and Aug. 1981, full defacto Indexation

B. Exchange Rate Pollcy

- Sept. 12, 1972 offlcial devaluation of the peso of 858 . Number of exchange rates reduced from 13 to 3 and then to 1. Partial convertibllity (current account only).

- A crawling peg system was followed unt 11 Feb. 1978. From Feb. 1978 to June 1979 the rate of devaluation was preannounced at a rate below ongoing inflation. In June 1979 exchange rate was flxed to the dollar as a way to provide an anchor to the ant1inflation program.

C. Fiscal and Monetary Policles

- In 1974 a fiscal reform that Indexed the tax system implemented a broad VAT at a 20 rate and eliminated most exonerations, was enacted. Broad expenditure cuts. Fiscal deflcit was reduced from 258 of GDP in 1973 to 2 ? in 1975.

- Signiflcant tightening in monetary control was attempted early on. However, during 1974 reserves accumulation became an Important source of money creation. Interest rates were freed and were very high unt1l 1980.
Poland

- Most prices freed during first week of January of 1990.

- Limited and lagged wage indexation.

- Jan. 1, 1990, officlal devaluation of the 2loty by 468. Exchange rate unification. Partial convertibillty (current account only)

- Exchange rate is fixed to dollar as a way to provide an anchor to the stabllization program.

- Fiscal adjustment attempted, mainly through reduction in expenditures on subsidies. Target for 1990 calls for an adjustment of the fiscal accounts of 5 of GDP.

- Control of net domestic assets of Central Bank.

- Interest rates ralsed by more than 4 times to 35 per month. 
Table 2 (cont.)

Chile

D. Trade Pollcy

- Rapid elimination of quotas, licenses and prohibitions.

- Sweeping tariff reform that slashed tariffs from approximately 1008 in 1973 to 208 in 1976 and 108 by 1979.

E. Privatization

- Rapld process of privatization of banks and firms nationalized during the Allende period. Banks privatized first. Forelgners particlpation limited in the privatization process. However, a flexible FDI statute was enacted.
Poland

- Rapid elimination of quotas and 11 censes.

- Reduction of 1mport tariffs.

- Plans drawn, 11ttle done (yet). 
TABLE 3

The Evolution of Real Money in Chile:

$1965-1978$

(percent)

\begin{tabular}{rrr} 
& $\frac{\mathrm{Ml}}{\mathrm{Py}}$ & $\frac{\mathrm{M3}}{\mathrm{Py}}$ \\
\cline { 2 - 3 } & & \\
1965 & 7.9 & 11.1 \\
1966 & 8.4 & 11.5 \\
1967 & 8.1 & 11.6 \\
1968 & 7.9 & 10.6 \\
1969 & 7.7 & 11.0 \\
1970 & 8.1 & 11.4 \\
1971 & 12.2 & 16.5 \\
1972 & 13.1 & 16.9 \\
1973 & 10.1 & 12.5 \\
1974 & 5.1 & 6.3 \\
1975 & 4.2 & 6.8 \\
1976 & 4.0 & 8.0 \\
1977 & 4.9 & 10.7 \\
1978 & 6.0 & 15.9
\end{tabular}

Source: Ministerio de Hacienda y Credito Publico. 
TABLE 4

Inflation In Chile:

$1973-1978$

(monthly percent increases in the $\mathrm{CPI}$ )

\begin{tabular}{|c|c|c|c|c|c|c|}
\hline & 1973 & 1974 & 2975 & 1976 & 1977 & 2978 \\
\hline January & 10.3 & 14.1 & 13.9 & 10.5 & 5.9 & 1.8 \\
\hline February & 4.1 & 24.5 & 16.5 & 10.1 & 5.8 & 2.4 \\
\hline March & 6.2 & 14.2 & 21.2 & 13.5 & 6.1 & 2.9 \\
\hline April & 10.2 & 15.3 & 20.8 & 11.9 & 4.7 & 2.6 \\
\hline May & 19.4 & 8.7 & 16.0 & 9.8 & 3.8 & 2.1 \\
\hline June & 15.6 & 20.8 & 19.8 & 12.3 & 3.3 & 2.0 \\
\hline July & 15.3 & 11.5 & 9.3 & 8.9 & 3.9 & 2.5 \\
\hline August & 17.1 & 10.9 & 8.9 & 5.5 & 3.4 & 2.8 \\
\hline September & 16.9 & 12.8 & 9.2 & 7.6 & 3.7 & 2.9 \\
\hline October & 87.6 & 18.9 & 8.4 & 6.7 & 4.2 & 1.9 \\
\hline November & 5.7 & 9.7 & 8.2 & 3.8 & 2.2 & 1.3 \\
\hline December & 4.7 & 6.5 & 7.1 & 5.1 & 3.1 & 1.5 \\
\hline Dec. to Dec. & 508.1 & 375.9 & 340.7 & 174.3 & 63.5 & 30.3 \\
\hline
\end{tabular}

* These data refer to official inflation. For a discussion of alternative measures of inflation in Chile see Edwards and Edwards (1991).

Source: National Bureau of Statistics. 
TABLE 5

Fiscal Deficit and Inflation In Chile:

$1970-1983$

\begin{tabular}{|c|c|c|c|c|}
\hline Year & $\begin{array}{c}\text { Inflation } \\
\text { Rate } \\
\text { (December- } \\
\text { December }\end{array}$ & $\begin{array}{l}\text { Gov. } \\
\text { Nev. } \\
\text { GDP }\end{array}$ & $\begin{array}{c}\text { Gov. } \\
\text { Expend. } \\
\text { GDP } \\
\end{array}$ & $\frac{\text { Deficit }}{\mathrm{GDP}}$ \\
\hline 1970 & 34.9 & 28.1 & 25.2 & 2.9 \\
\hline 1971 & 34.5 & 32.4 & 21.2 & 11.2 \\
\hline 1972 & 216.7 & 32.2 & 18.7 & 13.5 \\
\hline 1973 & 605.9 & 44.7 & 20.1 & 24.6 \\
\hline 1974 & 369.2 & 32.4 & 21.9 & 10.5 \\
\hline 1975 & 343.2 & 27.4 & 24.8 & 2.6 \\
\hline 1976 & 197.9 & 25.8 & 23.5 & 2.3 \\
\hline 1977 & 84.2 & 24.9 & 23.1 & 1.9 \\
\hline 1978 & 37.2 & 23.8 & 23.0 & .9 \\
\hline 1979 & 38.0 & 23.1 & 24.7 & -1.7 \\
\hline 1980 & 31.2 & 25.0 & 25.5 & -.6 \\
\hline 1981 & 9.9 & 23.7 & 26.7 & -3.0 \\
\hline 1982 & 20.7 & 29.0 & 26.7 & -2.3 \\
\hline 1983 & 23.1 & 28.4 & 24.6 & 3.8 \\
\hline
\end{tabular}

Sources: Column A is taken from Yañez (1978) for years 1970-72 and 1979-82 as published in Banco Central De Chile, Boletin Mensual (various 1ssues); from Cortazar and Marshall (1980) for 1973-78. Colums B through $D$ are taken frow de Castro (1981). 
TABLE 6

Wage Indexation In Chile:

1974-1980 (percentages)

(1)

\begin{tabular}{c} 
Per1od \\
\hline $10 / 1 / 73-1 / 1 / 74$ \\
$1 / 1 / 74-5 / 1 / 74$ \\
$5 / 1 / 75-7 / 1 / 74$ \\
$7 / 1 / 75-10 / 1 / 74$ \\
$10 / 1 / 75-12 / 1 / 74$ \\
$12 / 1 / 75-3 / 1 / 75$ \\
$3 / 1 / 75-7 / 1 / 75$ \\
$7 / 1 / 75-9 / 1 / 75$ \\
$9 / 1 / 75-12 / 1 / 75$ \\
$12 / 1 / 75-3 / 1 / 76$ \\
$3 / 1 / 76-7 / 1 / 76$ \\
$7 / 1 / 76-9 / 1 / 76$ \\
$9 / 1 / 76-12 / 1 / 76$ \\
$12 / 1 / 76-3 / 1 / 77$ \\
$3 / 1 / 77-7 / 1 / 77$ \\
$7 / 1 / 77-12 / 1 / 77$ \\
$12 / 1 / 77-3 / 1 / 78$ \\
$3 / 1 / 78-7 / 1 / 78$ \\
$7 / 1 / 78-12 / 1 / 78$ \\
$12 / 1 / 78-3 / 1 / 79$ \\
$3 / 1 / 79-7 / 1 / 79$ \\
$7 / 1 / 79-12 / 1 / 79$ \\
$12 / 1 / 79-4 / 1 / 80$ \\
$4 / 1 / 80-10 / 1 / 80$ \\
$10 / 1 / 80-8 / 1 / 81$ \\
$8 / 1 / 81-7 / 1 / 83$ \\
$7 / 1 / 83-1 / 1 / 84$ \\
\hline 13
\end{tabular}

(2)

(3)

End of Period

Mandated Nominal

Accumulated
Inflation

107.78

87.1

31.3

39.5

30.4

41.4

103.2

19.0

28.1

30.2

56.8

14.8

19.2

17.8

19.2

18.7

7.5

10.0

11.9

5.5

10.8

18.0

9.4

13.9

14.3

37.1

11.8
Wage Increase

$50.08^{\mathrm{b}, \mathrm{d}}$

$61.1^{\mathrm{b}}$

34.5

24.1

35.2

33.1

71.0

24.0

28.0

32.0

39.0

26.0

18.0

19.0

18.0

18.0

8.0

10.0

12.0

6.0

11.0

18.0

8.0

$14.0^{\mathrm{c}}$

$14.0^{\mathrm{c}}$

5. $0^{c, e}$

$15.0^{\mathrm{c}}$ 


\section{Table 6 (cont)}

${ }^{a}$ Corresponds to the official CPI

${ }^{b}$ Corresponds to Increase in minlmum wage.

c Not binding for workers subject to collectlve bargalning.

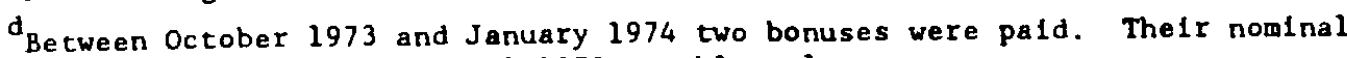
value was equal to the April 1973 taxable salary.

e The 23.4 loss in real income was partially offset by four bonuses of 30 , 15. 15, and 15 of current wages paid in September, October, November, and December 1983.

Source: Banco Central de Chile (1984) and A. Edwards (1985). 
TABLE 7

$1978-1983$ (percentage)

\begin{tabular}{cccc}
$\begin{array}{c}\text { Annualized Rate } \\
\text { Of Devaluation } \\
\begin{array}{c}\text { W1 th Respect To } \\
\text { U.S. Dollar }\end{array}\end{array}$ & $\begin{array}{c}\text { Annualized } \\
\text { U.S. WPI } \\
\text { Rate of } \\
\text { Inflation }\end{array}$ & $\begin{array}{c}\text { Annualized } \\
\text { U.S. CPI } \\
\text { Rate of } \\
\text { Inflation }\end{array}$ & $\begin{array}{c}\text { Annualized } \\
\text { Rate of } \\
\text { Inflation } \\
\text { (CPI) }\end{array}$ \\
\cline { 1 - 2 } 21.4 & 9.6 & 9.1 & 37.2 \\
14.9 & 14.9 & 13.3 & 38.0 \\
0 & 12.3 & 12.4 & 31.2 \\
0 & 5.6 & 8.9 & 9.5 \\
88.3 & 1.5 & 3.9 & 20.7 \\
19.2 & 1.8 & 3.8 & 23.1
\end{tabular}

Sources: All data refer to December to December rates of change.

Columns $A$ and $D$ are from Table 2-1.

Columns $B$ and $C$ are from the IMF International Financlal

Statistics. 


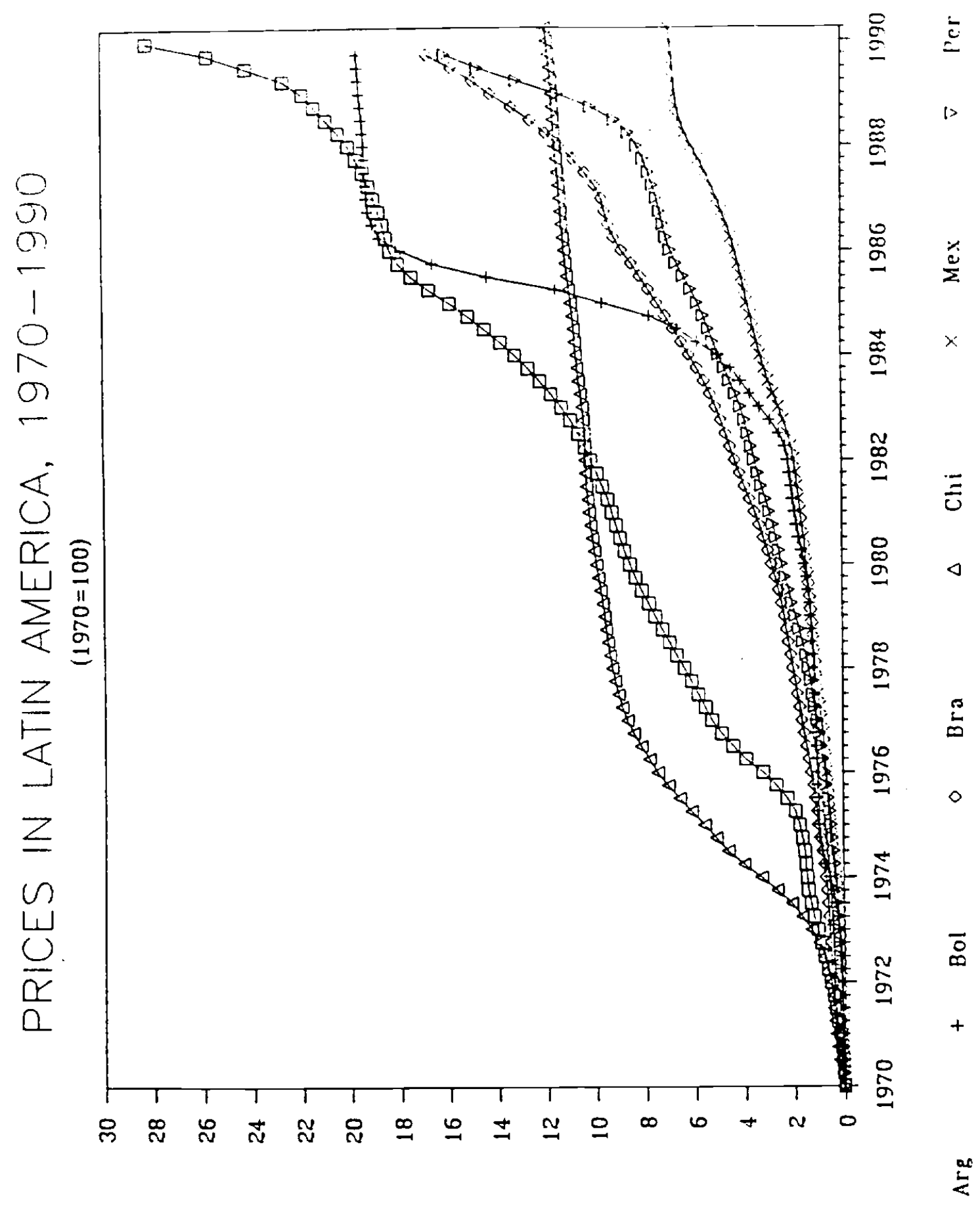




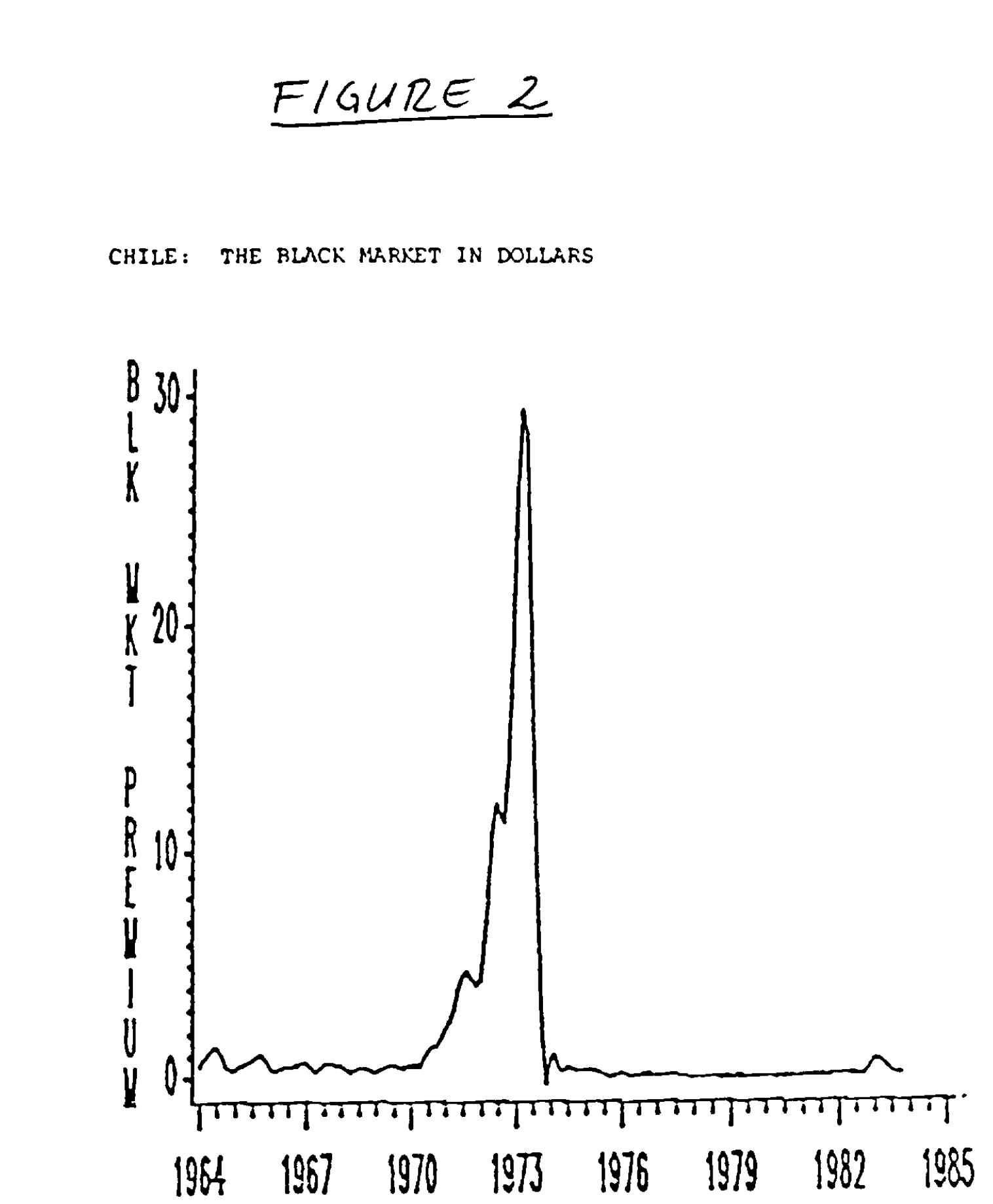


FIGURE 3

\section{PEAL EXCHANGE RATE}

\section{CHILE}

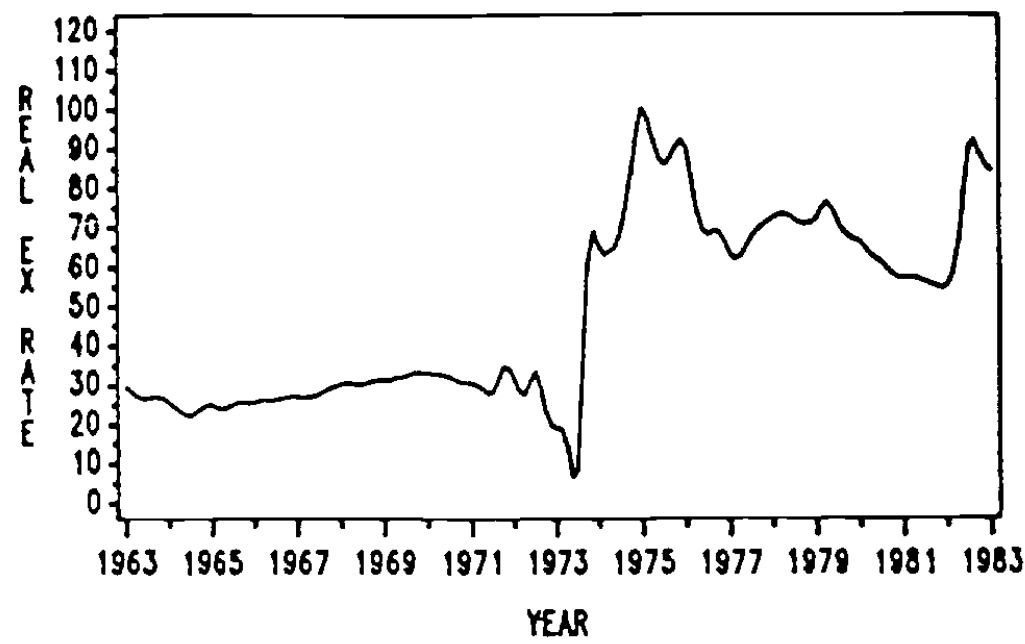

